SCIENCE ON A MISSION HOW MILITARY FUNDING SHAPED WHAT WE DO
AND DON'T KNOW ABOUT THE OCEAN

Book by Naomi Oreskes, 2021, The University of Chicago Press, 744 pages, ISBN: 978-0-226-73238-1, hardcover US \$40, e-book US \$39.99

Reviewed by Melbourne Briscoe

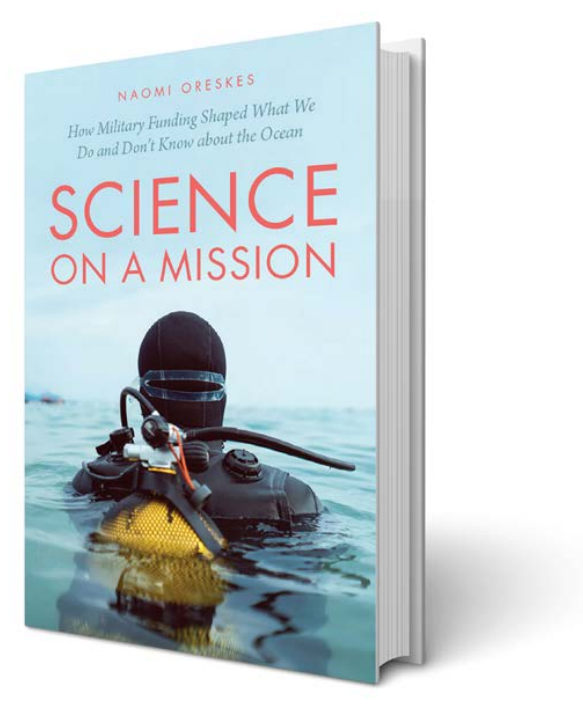

funders have specific goals and concrete purposes in mind. To allow that their research was funded by an outside organization with an interest in something other than the advancement of learning would be to raise the specter of taint. (page 472)

Oreskes appears to be quite taken with the "specter of taint," even though she is not able to call out any instances where it seems to have occurred. In fact, in the notes for Chapter 1, she points out:

... scholars who have studied scientific patronage have rarely been willing to claim that that patronage caused scientists to work in particular ways, much less to conclude certain things about the natural world. For instance, Shapin and Schaffer, [in] Leviathan, [and the Air-Pump: Hobbes, Boyle, and the Experimental Life] argued that general political principles and inclinations affected how Hobbes and Boyle interpreted the evidence of a vacuum, but they did not claim that their specific patrons caused these scientists to work on the questions they did. (page 513)

the book, Oreskes argues as part of her conclusions:

This helps to explain why so many scientists believe that "pure" or "basic" science is superior to that which is "applied," "directed," or "mission driven"; they believe that the latter is subject to potentially distorting external pressures to which the former is not. If so, it would make sense that scientists would insist on the purity of their research-on its basic and fundamental character-even when their

\section{THE BOOK}

The text has an Introduction, nine chapters, and a Conclusion section. The nine chapters are very people-oriented: Chapter 1 is very much about Harald Sverdrup; Chapter 2 about Henry Stommel; Chapter 3 about "The Woods Hole Palace Revolt” led by Stommel and Bill Von Arx; Chapter 4 about Harry Hess and seafloor spreading; Chapter 5 about Bruce Heezen and bathymetry; 
Chapter 6 about the human-occupied vehicle Alvin and the projects and people associated with the submersible in its early years; Chapter 7 about hydrothermal vents and a host of folks associated with that early work; Chapter 8 about Charlie Hollister and seabed disposal of radioactive wastes; and Chapter 9 about climate change but mostly about the Acoustic Thermometry of Ocean Climate (ATOC) project and Walter Munk's role. Oreskes acknowledges that portions of Chapters 1, 6, and 7 were previously published in various papers. Her geology background shows in the depth of her explanations of work and in some word choices.

As a personal note, I've had the pleasure in my career of at least meeting and in some cases working with many of the folks Oreskes talks about; they have been my mentors, my friends, and my colleagues. I'm sure that colors my views of them, but it also adds personal knowledge rather than being restrained to the materials in the archives.

As a side note, by basing her information almost completely on the written record, Oreskes misses what people actually thought as opposed to what they were willing to say or especially to write down. Who among us would write the same thing in a letter to a funding agency as we might say to a colleague? Yet, she closes with a quote from a letter written by Paul Fye, then director of WHOI, to the US National Science Foundation (NSF):

In a letter to NSF earth science director William Benson in 1959, he summarized his situation: "Since the war, the cost of ship operations, other than those related to applied research projects, has been borne mainly by the Office of Naval Research. Although this support has been generous, and in the case of physical oceanography has been unrestrictive in terms of specific research, these funds have been inadequate to provide an essential degree of freedom in the planning of field operations and the development of research programs. Such programs have always to a certain extent been dependent upon associations with military application-type research projects and this has invariably influenced to some degree the direction of the research itself.' Of course it did. How could it not? (page 502)
That is how she ends her text: taking the words of someone looking for additional funding for his institution, who is making an argument tuned to sound good to NSF, and twisting it in a snarky comment to suit her point of view.

I do not believe one should read this book without also reading at least two other books bearing directly on the issues Oreskes raises: An Ocean in Common (2001) by Gary E. Weir, and Pasteur's Quadrant (1997) by Donald E. Stokes. The former, which she references, covers roughly the same period (1919-1961) as does Oreskes but is based heavily on purposeful interviews as well as the archival record. It is also far more complete than Science on a Mission in coverage of many projects and activities rather than cherry-picking a few to try to support an apparently preconceived pointof-view. Pasteur's Quadrant, which she ignores, demolishes the artificial dichotomy between basic and applied research that was espoused in Vannevar Bush's Science, The Endless Frontier (1946) and that is used throughout Oreskes' book as the only way to think about things. Clearly, she had to ignore Pasteur's Quadrant because it makes nonsense of her thesis that research is pure or (mostly likely) tainted. A third book worth considering, and which she references, is Science and the Navy (1990) by Harvey M. Sapolsky, the history of the US Office of Naval Research (ONR). A fascinating read.

Oreskes also misses a lot of useful and relevant history. In addition to downplayingor simply not believing-the remarkably open-ended view about research that ONR held in its first decade and a half (19461960) and beyond, she ignores the fundamental role that the US Department of Defense (DoD) played in developing a new budgeting system in 1961 (https://fas.org/ sgp/crs/natsec/IF10429.pdf). Called PPBS (Program Planning and Budgeting System, now called PPBE_-Planning, Programming, Budgeting, and Execution), it introduced nine Program Areas (now 12) of which number 6 was Research and Development (https://www.acqnotes.com/Attachments/ DoD 70450.7H FYDP Structure.pdf, pages 9-10). Program Area 6 was further subdivided into:
6.1 Basic Research

6.2 Exploratory Development

6.3 Advanced Development

6.4 Demonstration/Validation

6.5 Engineering Development

6.6 Management and Support

"6.1 Basic Research" is what the university establishment is familiar with, and occasionally 6.2. Note the explicit definition of 6.1: "Includes all effort of scientific study and experimentation directed toward increasing knowledge and understanding in those fields of the physical, engineering, environmental, and life sciences related to long-term national security needs." (Note the "long-term," not shortterm or immediate.)

If you want to dig further, you can look at the actual budget documents submitted to Congress by DoD, called the "R-1" (https://comptroller.defense.gov/Portals/ 45/Documents/defbudget/fy2021/fy2021 r1.pdf). It is 242 pages of numbers, but on page 49 you will find an entry (Line 3 ) for the Program Element 0601153N, which is the Navy's basic research budget for FY2021.

What is the point of this digression?

- Point \#1 is that prior to 1950 and the formation of the National Science Foundation, ONR was the only postwar federal source for funding in research, as a direct result of Vannevar Bush's Science, The Endless Frontier.

- Point \#2 is that before the early 1960s ONR was the custodian of the Navy's research funding and was quite open about funding nearly anything that scientists wanted to do in the ocean, if it seemed to have the remotest relationship to national security.

- Point \#3 is that after the mid-1960s, the DoD budgeting system fenced off the basic research funds to further ensure they were spent on basic research.

Coupled with ONR being the only game in town in the first few years after the World War II and the major player in oceanography (as NSF grew) for the next decade, whether or not this was a bad thing or not is an interesting discussion, but those who lived and worked through that period-with a very small number of dissenters-did not appear 
to feel constrained in their quest to understand how the ocean worked, especially in physical oceanography. Oreskes pays a lot of attention to those few dissenters-for example, Stommel and Von Arx in Chapter 3and highlights their worry that they might get told what to do by the military. In fact, to my knowledge based on stories and working down the hallway from both of those gentlemen-never once were they told what to do by the military. The ONR mantrawhich we researchers learned about by word of mouth but which the ONR program managers were explicitly told by management to follow-was to find the best and brightest, fund them without hassle, and let them do what they wanted to do. Thus, the Stommels and Walter Munks (I can't believe I'm putting that in the plural) kept being funded and kept doing great things for understanding how the ocean worked.

There are some very good things about the book, but mostly those are not really related to its title or thesis; about a third of the book is devoted to long background digressions, such as the description of the history and development of the StommelArons model of abyssal circulation, and the personality aspects that helped and hindered work on seafloor spreading, bathymetry, and seabed disposal-all great stories (though I'm not sure why the story of seabed disposal of radioactive waste is even in the book, because it was not "military" funding.) I was less taken with her portrayal of ATOC-perhaps because of my personal involvement in the earlier Heard Island Experiment-but several times she shows dismay at the very thought that the military might be interested in climate change. In fact, she seems not cognizant of the Task Force Climate Change stood up by the Navy in 2009 (and disbanded by the Trump Administration in 2019 as "no longer needed").

Some things I do not like:

- Oreskes takes an Aristotelian view of basic versus applied science, ignoring modern views of the inadequacy of that simple concept, and then denigrates anyone doing applied science as quite possibly tainted since their motives of "the quest for understanding" are not pure. To be fair, she does mention (p. 485)
"Mode 1" and "Mode 2" science-somewhat related to Pasteur's Quadrantbut only in the context of Mode 2 being related to accountability and then asserts that the ATOC researchers behaved in a way that was not accountable to anyone other than themselves. Her unwillingness to go beyond the simplistic thinking of "it is either basic research or it is directed research" shows up even in the book's Introduction: "Throughout the Cold War and even after it was over, the oceanographers whose stories are told in this book insisted that they were doing 'basic research', and it is true that for the most part they were not trying to solve specific operational problems. However, we will see in these pages that the Navy supported oceanographic work not qua basic research but because it was salient to specific problems the Navy was trying to solve." (pages 6 and 7)

- Oreskes consistently forces this false dichotomy that basic research may not ALSO be applicable research. "Basic" describes the motivations and how the work is performed; "applicable" describes how that basic research might be used.

- She conflates ONR funding with mission components of the Navy (like BuShips), calls it all "military" and therefore "applied."

- She conflates problems caused by classification with problems caused by "directed" funding.

- She mentions the Mansfield Amendment of 1970 as further evidence that the military had a narrow and short-term view of what research to fund. In fact, it seems to have had little effect within DoD and Navy, specifically ONR. Note the official DoD language above for 6.1 research; nothing there about shortterm or directed research. I remember well in the early 1970s while I was working at WHOI that we submitted our proposals to ONR, were funded, and then later found an ONR document that described the "military relevance" of our work. It described things that were not in our proposals or oral discussions of the work and were entirely made up at ONR to make sure there was the requisite connection to long-term national security so we could be funded for what we wanted to do.

- She concludes Charlie Hollister was unable to change his mind on seabed disposal because he wanted to grow his audience and this "would have placed him at the center of an important policy question, making him a man on whom the US government would need to rely. It would place him in the limelightand for a long time." (page 392) Or, maybe Charlie just didn't like to admit he was wrong.

- She makes a big deal in several places about how the first three years of Alvin's work has been "expunged" from the record ("painting science white"), citing an article by Robert Ballard in an NSF volume about its first 50 years, and a Science article mentioning the science dives of Alvin. But what about Alvin's first three years, she asks? She is not comfortable with the engineering, checkout, and classified Navy-related dives that were done during those first years, including searching for USS Thresher, USS Scorpion, and an H-bomb off the coast of Spain. Oreskes' concern seems to be that the Alvin users wanted to ignore and hide its nonscience motivations and uses, so have tried to "expunge" that work from the record. She ignores the possibility that the writers in those publications were talking about the submersible's science dives rather than all the dives. Other publications are more comprehensive about those early years.

- Some random errors:

- The National Research Council (NRC) went away in mid-2015.

- Radio can indeed penetrate the ocean if the frequency is low enough.

- ONR did in fact fund the several NRC studies she mentions about acoustics and marine mammals, and that funding was not directed in the slightest. I know; I funded those studies while at ONR.

\section{SUMMARY}

Oreskes' thesis is that it makes a difference who is funding your work, and that difference is possibly-perhaps likely-negative. She loves to return to tobacco and pharma- 
ceutical research to make this point. She has tried to find examples in oceanography where such directed and tainted research exists. All she can come up with is "maybe," and some assertions that what was funded by ONR-no matter how fundamental or far-reaching-must have been valuable to the Navy because why else would they fund it? (She ignores the point that it might have been valuable and still have been fundamental and far-reaching.)

Oreskes thus poses the strawman: if the Navy knew it was NOT valuable to the Navy, then they were misspending public money, and if they knew it WAS valuable to the Navy, then does this not mean they were funding directed research? She argues:

Moreover, there is something peculiar about the claim that the ONR supported basic research without regard to salience - if this were true, it would stand at odds with its legal mandate to support research on behalf of the Navy mission. For ONR officials to have supported "pure research, with no strings attached," would have meant that they were not actually doing their job; they might even have been guilty of misappropriating federal funds. Wouldn't it make more sense to assume that they funded research that matched their goals, or that Navy funding involved various constraints, some innocuous but others perhaps not? (page 5)

Oreskes simply disallows the counterargument that one can perform basic research, selected by the researcher and aimed at improved understanding of some aspect of the ocean, and yet that same aspect can also be of interest to the Navy. She conflates applicable basic research with directed research. If she has an argument, it should be only that not all possible aspects of the ocean are applicable. But then, no matter the source of the funding, you can't fund everything-a fundamental principle in the funding business-so those funding sources that may have areas of interest may use possible applicability in their area of interest as one of the criteria for funding. This is NOT directed, applied research, no matter how many times Oreskes makes that claim.

Oreskes' prime example (that I can find in the book) of something NOT funded by
ONR was the search for a giant squid early in the Alvin days; this is used to argue that military missions did not allow this kind of work, so this implies the entire field of oceanography must have been subservient to the demands of the military.

The author misses the point made above-arguably the single most significant point about funding research-that you cannot fund everything, there must be some Yes and No decisions. One way to narrow the scope of possible research is to choose broad research areas...like physical oceanography and geophysics, which is what the Navy did. Early on, ONR searched for the best and brightest and did not worry about the topics-anything you learned about the ocean was probably valuable, especially in physical oceanography.

As time went on and the number of researchers greatly increased, the funding pressure increased; however, the available funding did not increase proportionally. When NSF came along, there seemed to be a chance to have two sources of basic research funding, but NSF did not have much money during the 1950s, and so decided NOT to fund anything that ONR was funding. NSF grew, ONR shrank, and the dilemma was exposed in 1970 with the Mansfield Amendment, which potentially would have moved over \$300M of funded basic research work from ONR to NSF, except that the NSF budget did not increase to accept those researchers. So ONR kept funding the people and programs it was already funding, and NSF said, "not our problem." Over the years, the attitude that "ONR funds this" and "NSF funds that" still persists, as one way for each agency not to have to address everything. The "this" and "that" also included people and programs, not just research topics. As a consequence, researchers discovered (for example) they could more easily develop new instruments under ONR funding than under NSF funding, and then more easily get NSF funding for extensive ship time to use those instruments. Everybody is happy. Oceanography benefits. The book ignores this.

There is an old saying: If I tell you to work on something, it is directed research; if you decide to do exactly the same thing without being told, it is basic research. That has been the genius of ONR: do NOT tell people what to work on, let them decide. But it is $\mathrm{OK}$ to expose them to problem areas about which little is known, fertile fields as it were. Many researchers love to get into a new topical area and skim the cream, do the first work, then move on and let others fill in the details. If this be tainted research, so be it. What it is, really, is what Oreskes calls the positive side:

On the positive side, patrons can encourage scientists to attend to neglected questions, consider matters from new angles and perspectives, or try a new approach. In medical research, we have seen how patients have positively influenced researchers who previously neglected important questions. Historians of technology have shown how the demands of industry and commerce can stimulate scientific innovation. (page 1)

Stokes, in his Pasteur's Quadrant, is particularly eloquent about the interplay between science and technology. But Oreskes prefers to assume-with little evidence that I can see-the negative dominates:

On the negative side, however, the interests of patrons may cause scientists to focus on immediate answers to pressing problems at the expense of fundamental understanding (which, as we shall see in this book, many Cold War oceanographers feared would happen to their field). (page 1)

It is not obvious that this fear was realistic. It is obvious that Oreskes' fear of taint is unproven. The book describes how some aspects of oceanography were indeed inhibited by military funding-notably classification of seafloor bathymetry-but hardly directed. In fact, the book is a paean to ONR and to those many researchers and administrators-within the Navy and academia-who searched for, and supported, fundamental understanding of the ocean. The Navy and society benefited from this. @

\section{REVIEWER}

Melbourne Briscoe (mel@briscoe.com) is President, OceanGeeks, LLC, Alexandria, VA, USA, and was a program manager and division director during 1987-1992 and 1996-2007 at the US Office of Naval Research.

\section{ARTICLE DO}

https://doi.org/10.5670/oceanog.2021.301 